\title{
Comparison of Multiculturalism Elements in Music Education between \\ China and Korea
}

\section{Rui Zhang}

\section{Shandong University,264209}

\begin{abstract}
Multicultural music education was recognized that it is necessary above all, to understand the nature of the music, which transcends all times and cultures, also to build a comprehensive musicianship. Through multicultural music education, we can expand our field of vision and openness to other cultures, so that we can extend our own cultural identity. In this study, we firstly elaborate the value of music education in multicultural background, and then respectively analyze Korean and Chinese multicultural music education reform history, and excavate the multicultural elements from music textbooks from these two countries.
\end{abstract}

KEYWORDS:Music Education; Multicultural Elements; Korea

\section{Introduction}

Multicultural education was produced and developed in multicultural nations like USA and Canadian. In the field of music education, multiculturalism is often regarded as began in the early twentieth century. At that time, the immigrants from other countries to America brought with their various music and dance culture, which had an impact on the school education. However, actually multicultural education in school was firstly put forward at Tanglewood Conference in 1967.The Conference adopted the "Tanglewood Declaration", Core philosophy of which was: all the time, all kinds of styles, forms and cultural music should be included in curriculum; music tracks should be extended, to make it accommodate a variety of music of our times, including teen pop music, avant-garde music, American folk music and the music of other cultures. The "Tanglewood Declaration" provided a unified guideline for music educators, and promoted the formation of multicultural music education ideas. Therefore, multicultural music education means to transcend a single culture of all nations, and the process of musical beauty mining and self-realization, through a variety of musical experiences of other ethnic groups.

In music education, Multicultural experiences more valuable than just learning a simple song. Korea musicologist Gwon deok-won put forward the value of music education in multicultural background, containing the following six aspects:

1) First, multicultural music education allows students to understand the different ethnic music, cultural, social, political and religious, so they can accept and respect other cultures.

2) Second, through the multiculturalism education, students can better understand themselves, and better understand other ethnic groups.

3) Third, make students accept the diversity and difference between different music. Music of each nation has its certain uniqueness, which cannot be compared with others. This not only 
means that the nation's music is different from each other, but also the judgment criteria of music are different.

4) Forth, multicultural music education contributes to a better understanding of its own music. The students who have experienced a variety of national music are easier to understand the uniqueness and aesthetic of their national music.

5) Fifth, multicultural music education can improve the students' creativity in music. Each music has unique logical way of music form, so if understand this logic, the music creativity will be more outstanding.

6) Sixth, multicultural music education help expand the conception of music. For example, when study the rhythm, the difference in learning effect between students who only learn the rhythm within the scope of western music and students who accept the multicultural music education is quite great.

In a word, in view of the values of multicultural music education, it is necessary in the school curriculum.

\section{Multicultural Music Education In Korea}

\section{A. Traditional Music Education}

Since 1954, South Korea education curriculum standard has been reformed seven times, and the seventh edition of curriculum standard was modified in 2007. Multicultural music education in Korea was promoted by its special social structure and music culture status. The goal of Korean music education is "with the world as the goal, to establish the identification of the particularity of Korean traditional culture and understanding of foreign music culture". Korean music tutorials advocated developing students' musical potential and creativity, and through music to express their feelings and thoughts, improve quality of their lives, and eventually cultivate the talents of all-round developed. In addition, in the context of Korean historical, social and cultural background, we can observe Korean attitude to understand and enjoy the multicultural music.

\section{B. Reformed Music Education}

To solve the defects in the seventh music curriculum practice, The South Korean Ministry of education has revised the course objectives, of which specific contents are shown as follow:

1) Emphasize the role of music education and music effect.

2) Pursue appropriate education curriculum, to adapt to learning characteristics of different stage students.

3) In order to improve the efficiency of traditional music education, seek more concrete and practical educational programs.

4) Focus on application of center education curriculum theory, stressed the unity of practice and life.

5) Accepted multicultural music around the world.

6) Respect the rights of students and their chose.

After revision, Korea's music education programs began to get rid of the separated state between western music and national music. World folk music, domestic and foreign pop music, Southeast Asian music, South American music, African music were all integrated into Korea's music education system, which was reflected in the In the education curriculum.

The constitution system of Korean reformed music education is shown in Fig. 1; 


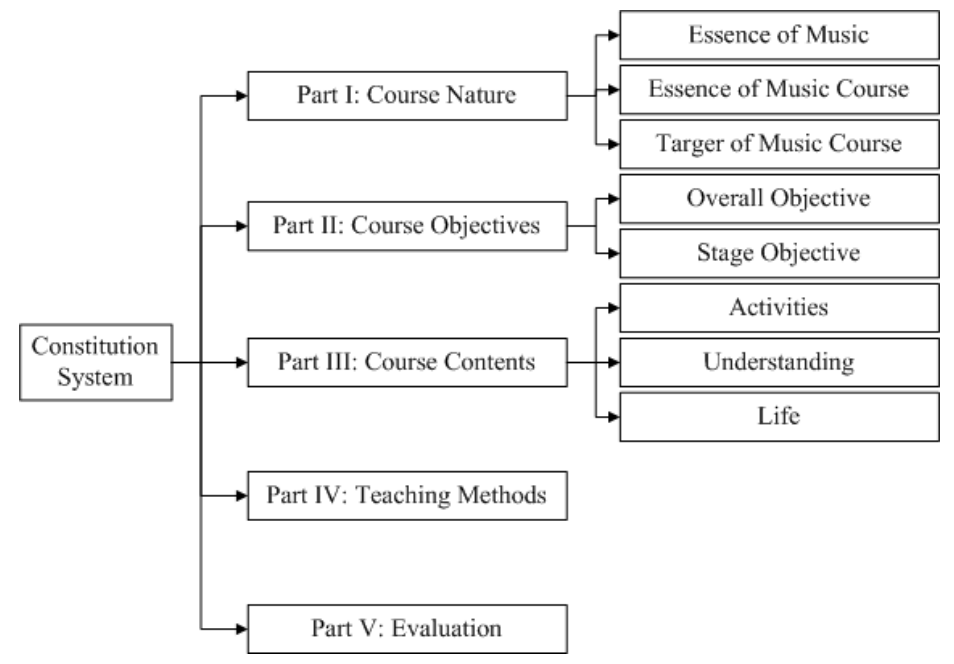

Fig.1. Korean Music Education Curriculum System

\section{Multicultural Elements}

Part of the multicultural elements in Korean music textbooks are shown in Table 1:

Table 1. Multicultural Elements In Korean Music Textbooks

\begin{tabular}{|c|c|c|c|}
\hline Item & \multicolumn{2}{|c|}{ Multicultural song } & Learning process \\
\hline \multirow[b]{2}{*}{$\begin{array}{l}\text { Around the } \\
\text { district }\end{array}$} & $\begin{array}{l}\text { Around the } \\
\text { district }\end{array}$ & Foreign song & Sing $\rightarrow$ comprehend $\rightarrow$ clarinet \\
\hline & $\begin{array}{c}\text { Music } \\
\text { appreciation: } \\
\text { canon }\end{array}$ & $\begin{array}{c}\text { Germany: Baja } \\
\text { bell }\end{array}$ & Concept learning of cannon \\
\hline \multirow{4}{*}{$\begin{array}{l}\text { The distant } \\
\text { country where } \\
\text { make friends } \\
\text { by music }\end{array}$} & Duck & Germany & \multirow{4}{*}{$\begin{array}{l}\text { Learn European music; } \\
\text { European cultural } \\
\text { understanding }\end{array}$} \\
\hline & Sarasponda & Netherlands & \\
\hline & $\begin{array}{l}\text { In Avignon } \\
\text { bridge }\end{array}$ & France & \\
\hline & Candles game & Hungary & \\
\hline $\begin{array}{l}\text { Peter and the } \\
\text { wolf }\end{array}$ & $\begin{array}{l}\text { Peter and the } \\
\text { wolf }\end{array}$ & $\begin{array}{l}\text { Russia: music } \\
\text { performance of } \\
\text { story }\end{array}$ & $\begin{array}{l}\text { Learn how to tell story by } \\
\text { music }\end{array}$ \\
\hline Small world & Small world & Foreign song & $\begin{array}{l}\text { In accordance with the } \\
\text { director and rhythm }\end{array}$ \\
\hline Dew & $\begin{array}{c}\text { Music } \\
\text { appreciation: } \\
\text { collar }\end{array}$ & France & Consider the music mood \\
\hline
\end{tabular}

In the music textbooks, the song "The Distant Country Where Make Friends by Music" reflects the treatment of the subject integration of multi culture. Judging from the concrete 
contents, the textbooks recruit Germany, Netherlands, France, Hungary songs, and synchronously introduce national life, culture, folk games and other content in each country, so that students can understand national cultures while learning music.

From the perspective of multicultural music education, the multicultural elements in the seventh education programme were not enough, but most of them were remedied in the revised education curriculum. What is most particularly worth mentioning is the complementary of practical content. Multicultural education not only helps to learn about different cultures facts, but also a deep understanding of other people's lives, history, culture and music.

\section{Multicultural Music Education In China}

\section{A. Multicultural Education Reform}

\section{Background}

In 2010, China held the 29th World Conference on music education, which brought the multicultural music education ideas from abroad. Over the past decade, development in the field of music education is very fast, and revision of curriculum standards was imminent. Later, 2011 revised edition of music education curriculum was introduced, because the 2001 edition no longer met the changes and social changes of the times. In addition, the 2011 revised edition completely broke the nature of the previous experimental version, been issued as the formal guidance material of nation compulsory courses.

\section{B. Music Education Standards}

(1) Curriculum System

China's music education program is divided into four main parts: foreword, course objectives, contents standard and implementation recommendations. The music education constitution of 2001 edition and 2011 revised edition are shown in Table 2:

Table 2. Comparison Of Constitution Between 2001 Edition And 2011 Edition

\begin{tabular}{|c|c|c|}
\hline & 2001 EDITION & 2011 EDITION \\
\hline $\begin{array}{c}\text { PART I: } \\
\text { PREFACE }\end{array}$ & $\begin{array}{l}\text { 1. curriculum nature and value; } \\
\text { 2. basic idea; } \\
\text { 3. design ideas of curriculum standards. }\end{array}$ & $\begin{array}{l}\text { 1. curriculum nature; } \\
\text { 2. basic concept of curriculum; } \\
\text { 3. design ideas of curriculum }\end{array}$ \\
\hline $\begin{array}{l}\text { PART II: COURSE } \\
\text { OBJECTIVES }\end{array}$ & $\begin{array}{l}\text { 1. overall objective; } \\
\text { 2. stage objective }\end{array}$ & $\begin{array}{l}\text { 1. overall objective; } \\
\text { 2. stage objective }\end{array}$ \\
\hline $\begin{array}{l}\text { PART III: } \\
\text { COURSES } \\
\text { STANDARD }\end{array}$ & $\begin{array}{l}\text { 1. feeling and appreciation; } \\
\text { 2. expression; } \\
\text { 3. creation; } \\
\text { 4. music related culture }\end{array}$ & $\begin{array}{l}\text { 1. feeling and appreciation; } \\
\text { 2. expression; } \\
\text { 3. creation; } \\
\text { 4. music related culture }\end{array}$ \\
\hline $\begin{array}{l}\text { PART IV: } \\
\text { IMPLEMENTATI } \\
\text { ON } \\
\text { RECOMMENDA } \\
\text { TIONS. }\end{array}$ & $\begin{array}{l}\text { 1. teaching recommendations; } \\
\text { 2. evaluation recommendations; } \\
\text { 3. curriculum resources exploitation and } \\
\text { utilization; } \\
\text { 4. proposals for compiling textbooks }\end{array}$ & $\begin{array}{l}\text { 1. teaching recommendations; } \\
\text { 2. evaluation recommendations; } \\
\text { 3. proposals for compiling textbooks; } \\
\text { 4. curriculum resources exploitation and } \\
\text { utilization }\end{array}$ \\
\hline
\end{tabular}


(2) Content Features

The content standards of China's music education program are divided into feeling and appreciation, expression, creation and music related culture, specific explanations as follow:

1) Feeling and appreciation: feeling and appreciation is an important field of music learning, and an effective way to cultivate students' ability of aesthetic appreciation of music. The formation of good music feeling ability and appreciation is of great significance to enrich students' emotion and promote physical and mental health.

2) Expression: expression is the basic content of music learning. In teaching process, teachers should focus on cultivating students' confidence in singing, playing and comprehensive ability of art performance. Through the music practice activities, let students learn to express personal emotions and establish communication the form of music.

3) Creation: creation is the music learning field to develop students' imagination and potential thinking, which is of great significance to cultivate innovative talents. Music creation includes two aspects of learning content: one is improvised musical innovations activity that aims at developing students' potential; the other is music creation attempt and practice with music materials.

4) Music related culture: music related culture is a concentrated expression of the music class humanities attribute, conducive to expand students' music cultural horizons. Although this teaching content has its own relative independence in some respects, it is often embedded in music appreciation, performance and creativity.

\section{Multicultural Elements}

Part of the multicultural elements in Korean music textbooks are shown in Table 3

Table 3. Multicultural Elements In Korean Music Textbooks

\begin{tabular}{|c|c|c|}
\hline Item & Form & Song Name \\
\hline \multirow{2}{*}{ Our field } & Sing & Field in the call (Italian folk songs) \\
\cline { 2 - 3 } & Activity & Pastoral caprice (France Bizet song) \\
\hline Shan shepherd & Sing & Vaquero (Slovak folk songs) \\
\hline Bridge hometown & Sing & In Avignon bridge (France) \\
\hline \multirow{2}{*}{ Music story } & Enjoy & Doll dream (Norway) \\
\cline { 2 - 3 } & Enjoy & Mother goose suite (France) \\
\hline \multirow{3}{*}{ Music box } & Enjoy & Vienna octave bell (Hungary) \\
\cline { 2 - 3 } & Enjoy & Typewriter (America) \\
\cline { 2 - 3 } & Sing & Jingle bells (America) \\
\hline \multirow{3}{*}{ Global folk songs } & Sing & Papaya Cha Cha Cha (Indonesia) \\
\cline { 2 - 3 } & Enjoy & Nile theme song (Japan) \\
\cline { 2 - 3 } & Sing & Red Dragonfly (Japan) \\
\cline { 2 - 3 } & Enjoy & Train Kakaka (Argentina) \\
\hline
\end{tabular}




\section{CONCLUSIONS}

For Specific examples, "Global Folk Songs" item is mainly multicultural music. In "Papaya Cha Cha Cha", it briefly introduces the Indonesia geographical location and the capital; prompt method of the "Nile Theme Song" is almost the same, illustrating the historical significance of the Nile; while "Red Dragon fly"introduces the geographical location and the capital of Japan.

\section{REFERENCE:}

[1] Howard K. Perspectives on Korean music[M]. Ashgate Publishing, Ltd., 2006.

[2] Volk T M. Music, education, and multiculturalism: Foundations and principles[M]. Oxford University Press, 2004.

[3] Griswold H E. Multiculturalism, music, and information highways[J]. Music Educators Journal, 1994: 41-46.

[4] Abril C R. Learning outcomes of two approaches to multicultural music education[J]. International Journal of Music Education, 2006, 24(1): 30-42.

[5] Multicultural perspectives in music education[M]. R\&L Education, 2011. 